\title{
THE CONVERGENCE OF POLITICAL AND
}

\section{GOVERNMENT ADVERTISING: THEORY VERSUS}

\section{PRACTICE}

\section{Sally Young}

\begin{abstract}
Although they are sometimes confused, in theory, government and political advertising are separate and quite distinct. By convention, government advertising, paid for directly by taxpayers, is to be used only for necessary government information campaigns which are neutral in manner and not liable to be perceived as creating a partisan benefit for the ruling party. By contrast, political advertising occurs predominantly during elections, is paid for by political parties or candidates and is necessarily partisan, persuasive and usually highly emotive, in nature. However, in the past two decades, these distinctions have broken down. This paper explores the growing links between the two types of advertising at the federal level and concludes that there is a vast gap between the theory and reality of government advertising.
\end{abstract}

In Australia, various interest groups sometimes advertise to try to draw attention to their causes or to influence political debate and decision-making. However, this is dwarfed in cost and consistency by the type of political advertising which occurs during elections and is paid for by political parties and candidates. Political (election) advertising of this kind is inescapably partisan in nature, persuasive in function and often highly emotive in nature. It is created by parties and candidates for the purpose of winning voter support.

One of the most famous examples of Australian political advertising is the Australian Labor Party's (ALP) 1972 television advertisements featuring celebrities singing the 'It's time' jingle. Recalled by many Australians, these ads were judged to be highly successful in winning over voters to the Gough Whitlam-led Labor Party (Young, 2004: 8-27).

In 1993, another famous campaign further convinced Australian politicians of the power of advertising. During the election, the ALP ran a series of hard-hitting negative television ads in 
response to the Liberal Party's plan to introduce a Goods and Services Tax (GST). Many commentators had expected the Liberal Party to win the election but, when the ALP won, it soon became conventional wisdom that the ads had played a significant role in the election result (Warneford, 1993: 15-6). Since 1996, commentators and advertising insiders have argued that the Liberal Party has been winning the election advertising battle with highly negative ads targeting Paul Keating, Kim Beazley and Mark Latham (Young, 2005b).

By convention (rather than legislation or stringent guidelines), government advertising has traditionally been seen as vastly different in purpose and nature from this sort of political (election) advertising. In theory, the traditional convention both major parties claimed to adhere to when in government was that government advertising, because it is paid for directly by taxpayers, was to be used conservatively and only for necessary government information presented in a 'neutral' manner so that the advertising was not liable to be perceived as creating a partisan benefit for the ruling party (e.g. see DPMC, 1982).

However, over the past two decades there has been a shift toward more controversial advertising which critics claim is blatantly 'partisan' in nature. This shift is being driven by a number of trends in campaigning practice and the political, social and economic climate of post-1980s Australia. In particular, there has been a growing proportion of swinging voters and often tight electoral contests between the two major party groupings (see McAllister and Bean, 1997: 177; Young, 2004: 43-57). These trends have been accompanied by a move to 'permanent' campaigning which has meant the parties no longer confine their campaigning to the official election period but instead seek to constantly campaign throughout the electoral cycle (Blumenthal, 1980).

All of this has encouraged parties, when in government (and at both state and federal levels), to increasingly use incumbency benefits and taxpayer-funded resources to obtain an advantage over their opponents (Young, 2003). Over the past decade in particular, there has been a blurring of what were, in theory, two distinct types of advertising. This paper will focus on seven major trends which demonstrate the increasing convergence of political and government advertising: spending, regulation, timing, advertising agencies, content, media placement and audiences.

\section{Spending patterns}

There is now an entrenched view among politicians that advertising is not only a suitable means of communicating with citizens, but an ideal one. The evidence for this is dramatically increased spending on both political and government advertising.

Figure 1 shows that 1996 was a key turning point in election advertising. The result of the 1993 GST election which, as discussed above, was widely held to have been advertising- 
influenced, precipitated a significant jump in spending between 1993 and 1996 as the major political parties' faith in advertising as an essential campaign tool was strengthened. There were also economic factors at play. In 1984, the Hawke Labor government had introduced public funding of election campaigns which sees taxpayer funding used to reimburse election candidates for their campaigning expenses. In 1995, the rate of public funding was increased significantly, giving the parties more money to spend on advertising (Young, 2004: 116-9).

Figure 1 - Political (election advertising) in \$ millions, 1974-2004

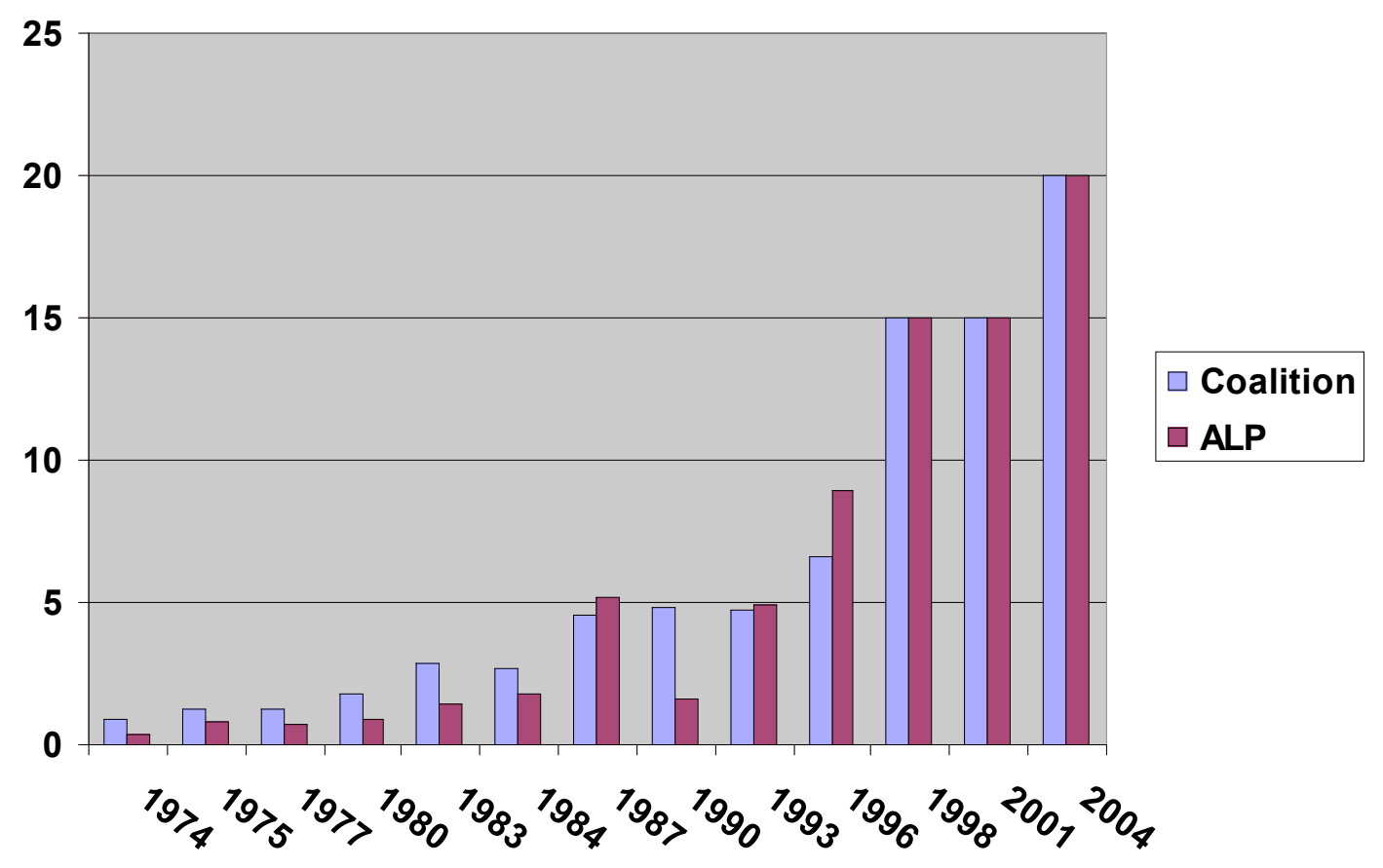

Sources: AEC funding and disclosure reports as outlined in (Young 2004: 41). Industry estimates, although very broad, must be used for figures for 1998-2004 as changes to the Commonwealth Electoral Act in 1998 removed the requirement for political parties to disclose breakdowns of their campaign expenditure.

At the same time as politicians' reliance on political advertising grew in the mid-1990s, government advertising also dramatically increased. Figure 2 shows advertising increased in 1995 and 1996 after the Keating Labor government's 'Working Nation' advertising campaign on unemployment. Government advertising expenditure continued to climb after the Howardled Coalition government came to power in February 1996. Two years later, for the first time, government advertising spending exceeded \$200 million. This was mainly due to GST campaigns in 1998-2000. Although spending dropped in 2001, high spending (of over $\$ 100$ million) had been normalised and has continued ever since. 


\section{Figure 2 - Federal government advertising expenditure, 1991-2004}

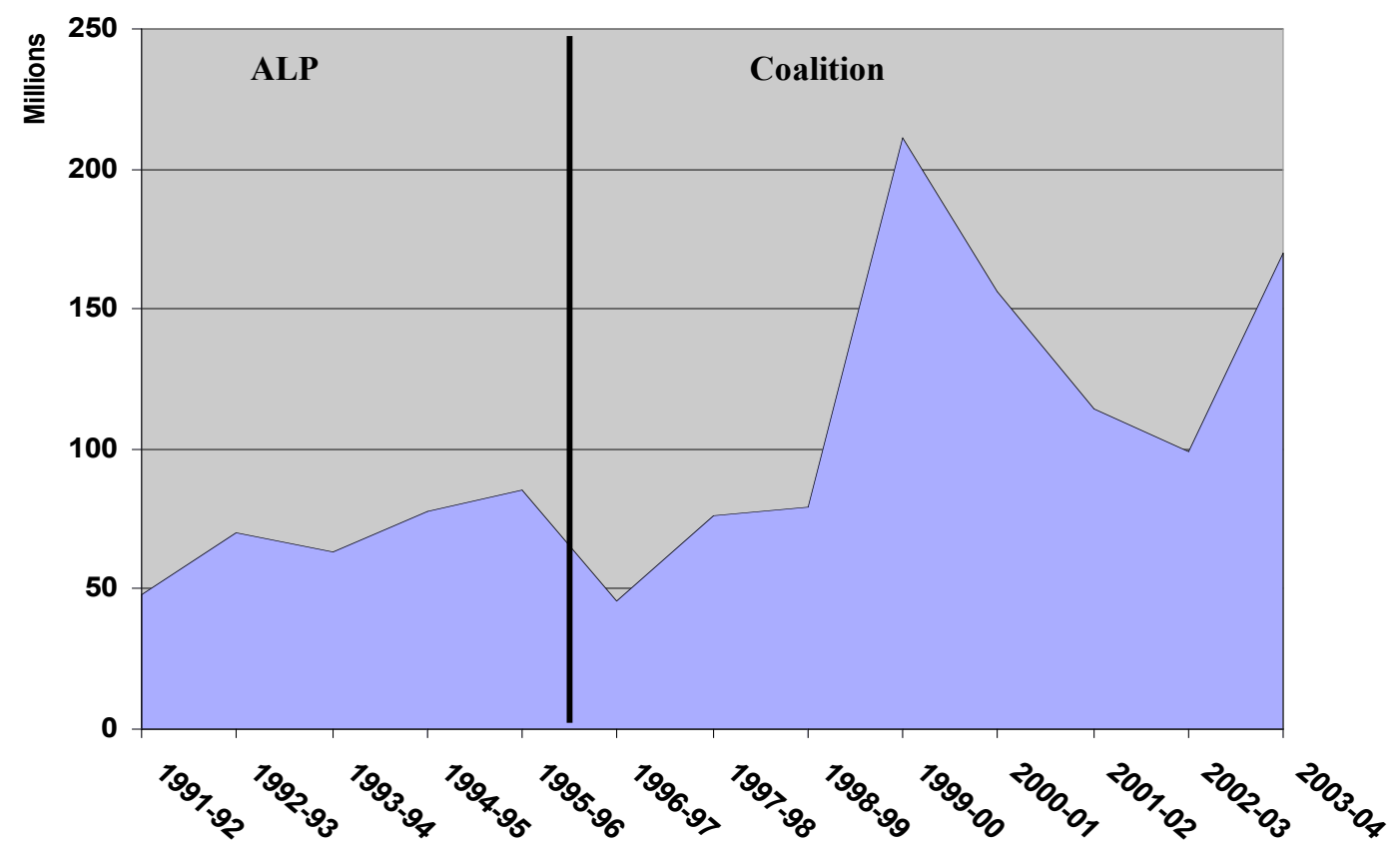

Note: Expenditure includes aggregate expenditure. Amounts shown are nominal figures. Source: for 1991-92 to 2002-03 is (Grant 2003-04: 2). Amounts shown for 2003-04 are based on later information provided by the Parliamentary Library (Young 2005a).

Spending of $\$ 100$ million per annum is extraordinary even by commercial advertising standards (see Sinclair, 2002: 204-5). The federal government is now frequently listed as the top advertiser in the country with the NSW, Victoria and Queensland state governments regularly listed in the top 20. In 2005, the Howard government spent more on advertising its 'Workchoices' industrial relations (IR) program in one month ( $\$ 55$ million) than McDonalds spent for the whole year of 2004 (Nielsen Media Research, 2005; Hawthorne, 2005).

State and territory governments - including Labor governments in NSW, Victoria and Queensland-have also spent heavily on advertising. According to the Department of Prime Minister and Cabinet (DPMC), state and territory governments spent $\$ 2.148$ billion on advertising between 1996 and 2003 (DPMC, 2004: 4).

Taking their cue from political campaigns, once in government, Australian politicians have continued advertising with a degree of enthusiasm that rivals even the commercial sector. Increased spending is not only due to perceptions about the power of advertising to persuade. Conveniently, advertising is also a one-way communication method. TV ads, for example, do not provide viewers with the opportunity to talk back, ask questions or disagree. Politicians also have complete control over the content. In an era of information control and media 
management (see Franklin, 1994; Golding ,1990; Street, 2001), political and government advertising use is booming.

\section{Regulation}

A second increasingly apparent similarity between political and government advertising in Australia is that, by international standards, extraordinarily lax rules apply to both. Unlike many other comparable countries, there are no limits on how much parties or candidates can raise from private donations to pay for political ads and no limits on how much they may spend on advertising. Unlike commercial advertising which comes under the Trade Practices Act 1974, at the federal level, there are no laws prohibiting lies or misrepresentations in political ads (see Young, 2004: 168-89).

A similarly laissez faire approach applies to federal government advertising which is regulated through a set of very broad and weak guidelines. When in opposition, the Liberal Party complained about the feebleness of the Guidelines for Australian Government Information Activities, drawn up under the ALP government in February 1995, however, since taking office in 1996, it has retained them. These guidelines say nothing at all about the potential for government advertising to be misused for party-political purposes. This is a curious omission. Most other countries have either legislation (in the US, for example) or guidelines which mention potential misuse (including in Canada, the UK and New Zealand) (Young, 2005a).

For example, New Zealand's guidelines have been in place since 1989 and specifically state that: 'Government advertising should be presented in unbiased and objective language, and in a manner free from partisan promotion of Government policy and political argument'. They also state that 'Factual information should be outlined clearly and accurately. Comment on and analysis of that information, to amplify its meaning, should be indicated as such' (NZ Audit Office, 1989; NZ Cabinet Office Circular, 1989).

Lack of regulation in Australia leaves a great deal of latitude for politicians (as both contenders for office using public funding and then as incumbents once in government) to determine how much they will spend on advertising. This open access to the public purse has resulted in the massive spending discussed above. The lax rules also allow politicians a degree of control over the content of their advertisements which politicians in most other comparable countries do not have (particularly in regard to government advertising). As a result, we are increasingly seeing content described as 'partisan' and ads timed for political advantage. 


\section{Timing}

Televised political advertising is usually broadcast during an election campaign and especially during the final two weeks. However, in theory, the timing of government advertising should bear no relationship to the timing of an election and, if truly 'neutral' and not being misused for political advantage, we would expect government advertising to occur independently of election campaigns. However, figures on government advertising spending clearly show that spending rises in election years (Grant, 2003-04).

An Auditor General's (1998) report found that there was a dramatic leap in spending just before the 1998 election. In 2004, only months before the election was announced, the federal government broadcast a series of ads on a range of policies including Medicare (discussed in more detail below). Newspoll reported that the government's primary vote slowly built up over this period and the Labor Party attributed this to the government's 'feel good' promotional advertising ('Howard cautions against poll boost', 2004; Clarke, 2004).

Aside from running ad campaigns just prior to an election, another controversial timing feature is the use of government advertising to promote a major law change before the legislation has been passed and, therefore, before specific information can be given to citizens. This sort of pre-legislation government advertising has occurred particularly in two instances at the federal level; in connection with the GST advertising in 1998 (see Harris, 2005) and in 2005 in the lead up to changes to industrial relations (IR) law.

The Howard Government's 2005 'Workchoices' IR advertisements were produced and broadcast before legislation to enact any changes had been drafted, let alone introduced into parliament or passed. The context of the campaign was significant as it was designed, quite rapidly, in response to an $\$ 8$ million advertising campaign run by the Australian Council of Trade Unions (ACTU) which had been highly critical of the government's proposed changes (Sinclair, 2005a).

Several aspects of the timing of government advertising are pushing the boundaries of hitherto accepted conventions about what is fair use: pre-election government advertising spikes; advertisements promoting a future change in law before the legislation has been passed and government ads which appear defensive and designed in response to an opponent group's ads or publicity. These factors indicate a growing congruence between political and government advertising and a move away from hitherto accepted conventions. 


\section{Advertising agents}

A fourth very significant link between political and government advertising which helps to explain the factors already discussed, is the increasing use of the same ad agents for both types of advertising.

In 1986, the Hawke Labor government launched the Australian Made campaign, with the patriotic jingle 'Hey True Blue' urging Australians to buy locally made products. The ads were devised by John Singleton who then produced the ALP's election advertisements in 1987 and continued as Labor's ad agent until 1996 (Buckley, 1986; Young, 2004: 89-93). In 1995, the actor Bill Hunter appeared in 'Working Nation' advertisements for the Keating Labor government. A year later, Hunter went on to star in Labor's election ads.

However, since the Howard government took office in 1996, there have also been a number of cases linking personnel associated with the Liberal Party to major government advertising campaigns. To provide some context to this it is necessary to consider the Liberal Party's election advertising structures. In 1995, the Liberal Party chose to forgo its usual use of one ad agency to create its election ads and instead handpicked a team of advertising and marketing experts - dubbed 'The Team' (or the 'Dream Team'). The Team's leader was Mark Pearson, a Sydney-based consultant and the other members were Ted Horton, Toby Ralph and John King (Young, 2004: 97-98). The Liberal Party has used this 'Team' on all federal elections from 1996-2004.

\section{Gun buy-back advertising}

In 1996, following the Port Arthur massacre in Tasmania and the introduction of new national firearms laws, the Howard government launched an advertising campaign informing gun owners of their rights and responsibilities and advertising the gun buy-back scheme. The ad agency DDB Needham Adelaide (DDBNA) was appointed to handle the \$3 million advertising campaign (Strickland, 1996: 30). At this time, DDBNA was 60 per cent owned by John King and Toby Ralph, both members of 'The Team' (Tingle et al., 1996: 3).

Evidence given to a Senate committee revealed that Prime Minister Howard's chief political adviser, Grahame Morris, had 'intervened twice' in the supposedly independent selection process 'to ensure [the agents] with Liberal Party ties won...' the advertising contract even though an independent assessment of the DDBNA pitch was damning and described its proposal as 'threatening, challenging, extreme [and] sexist...' (Tingle et al., 1996: 3). Morris and Senator Nick Minchin, who had both worked with DDBNA when they were Liberal Party state directors, were on the selection committee which made the final decision ('Mate's Job', 1996; Seccombe, 1996). 
That DDBNA won the advertising contract despite criticism from the Attorney General's Department, professional researchers and the Office of Government Information and Advertising (OGIA), and apparently only after intervention by the Prime Minister's office, led to concerns that an agency with political connections had seemingly gained 'an undue advantage over their competitors' ('Mate's Job', 1996). Such claims are of concern to the advertising industry because government contracts are particularly lucrative and, as John Sinclair (2002: 208) has noted, advertising 'is a competitive business...'.

\section{GST advertising}

In 1998, when the federal government decided to mount a large pre-election GST advertising campaign using taxpayers' money (as mentioned, before the legislation had been drafted or passed), the Australian Financial Review predicted that it would want to avoid suggestions of 'jobs for the boys' and this would therefore 'rule out' agencies such as DDB (Fox, 1998: 33).

While the government initially chose US multinational McCann-Erickson for the first stage of the government GST campaign in 1998 (Taylor, 1998), the contract for the second stage went to Mark Pearson, leader of 'The Team'. By that stage, Pearson had been working on Liberal Party campaigns for around 10 years ('Pearson's not the job for the boys', 2000). This second round of GST promotion was estimated to be worth up to $\$ 400$ million (Carmody quoted in SELC 2000: 43).

Significantly, key changes had occurred in the institutional structures and processes of government agencies during the period between the first and second stages of the GST advertising. In October 1998, the OGIA was relocated from the Department of Finance and Administration to the Prime Minister's own department. The Labor Opposition argued that this removal of 'the arms-length supervision' of the Department of Finance would allow the Prime Minister's office to 'seize control of government propaganda' and have 'direct control' over the Commonwealth advertising budget (Taylor, 1998: 6).

\section{The MCGC}

Under the structure resulting from these changes, there are now two main bodies responsible for government advertising: the Ministerial Committee on Government Communications (MCGC) and the Government Communications Unit (GCU) which is the renamed unit situated within the Prime Minister's Department. The MCGC makes the final decisions regarding 'major and/or sensitive [federal government] information activities' (GCU, 2005). As Stephen Bartos (2004: 7-8) points out: 'The MCGC does not answer to Parliament for its actions... [and] provides no annual report. It is difficult to find out what its charter is or even who its members are. [It] does not have a website, nor does it provide public statements. Its operations are among the most obscure of any government decision making body.' 
When details were released in 2004, the MCGC's members included Petro Georgiou, a former secretary of the Victorian branch of the Liberal Party, who 'masterminded the Guilty Party attack ads' on the Victorian Cain and Kirner Labor governments, as well as Tony Nutt, a member of the Prime Minister's staff and a former state director of the New South Wales branch of the Liberal Party, described as one of 'the party's tough conservatives and machine men...' (McGregor, 1998: 4) and an 'experienced apparatchik' (Walker et al., 2001: 21).

As at 31 October 2005, as disclosed to a Senate inquiry, the MCGC's members were Senator Eric Abetz, Tony Nutt, Petro Georgiou, Tony Smith (a Liberal MP), Andrew Robb (Liberal MP and former federal director of the Liberal Party who helped establish 'The Team' in 1996) and Sussan Ley (parliamentary secretary and Liberal MP) (Senate FPAC, 2005a). The MCGC demonstrates the growing links between political and government advertising as it is partisan and includes several former officials of the Liberal Party who have had significant involvement in election advertising as campaign directors.

\section{IR advertising}

In 2005, it was revealed that the agent approved by the MCGC to produce the politically sensitive IR ads was the firm Dewey Horton whose principal is Ted Horton, long-standing member of 'The Team' (McIntyre, 2005a). The 'public relations consultant' appointed to the IR advertising was Jackson Wells Morris. Since leaving Howard's office, Grahame Morris had been a partner of Jackson Wells Morris and continues to be a major shareholder (Senate FPAC, 2005a: 81). It was also revealed that Mark Pearson was working on the IR campaign 'as a contractor to Dewey Horton' prompting Senator Chris Evans to declare that it was 'the same circle of [Liberal Party] mates getting paid with taxpayer's money all the time' (Senate FPAC, 2005: 80).

The many links and connections have led to a perception of 'cosy deals' (McIntyre, 2005b) between partisan and government work which have prompted some serious allegations. In 2004, the Clerk of the Senate, Harry Evans (2004: 2), provided a submission to a Senate Inquiry into Government Advertising which stated 'It is suspected that advertising firms accept lower fees for advertisements paid for by the party in power with an assurance that more lucrative government advertising contracts will fall their way. In effect, the expenditure on the government advertising project subsidises the party-political advertising of the government party. This is tantamount to corruption'. This was a claim that provoked a furious response from the MCGC chairman (Abetz, 2004). Evans responded that allegations of 'cross-subsidising' have 'been made in the Senate on numerous occasions' (Evans, 2005).

Because those who approve and create government ads are now often the same individuals who work on election campaign advertising, it is not surprising that patterns in the media placement and content of government advertising are mirroring trends in political advertising. 


\section{Media placement and content}

There are many media and communication options a government can choose to inform citizens of changes to their rights, responsibilities or entitlements. For example, in 2004, when there were changes to family tax which would see an extra $\$ 600$ paid to recipients, rather than merely writing letters to the recipients to advise them of an increase, the federal government instead paid for a series of full page newspaper advertisements which largely consisted of a photograph plus a brief text message that stated: 'If you were receiving Family Tax Benefit Part (A)...you qualify... you don't have to do anything to claim your money; it will be paid automatically into your bank account' (Australian Government, 2004a).

This prompted questions about how the government could justify paying at least $\$ 25,000$ for each full-page newspaper ad when those new entitlements were directed at a very specific group (who could have been contacted directly by the relevant department that administers their benefits via letter). Rather than communicating directly with the affected target group, it seemed that the government was aiming to widely promote some 'good news' to a much larger audience.

A similar claim has been made in relation to government advertising on television. Television is a medium which not only has high emotional impact, due to the combination of visual and auditory content, but it also reaches a mass audience (Flew, 2002: 173-4). This makes it doubly attractive for promotional-style government advertising.

Figure 3 reveals that, until 1998, the federal government was spending approximately the same amount on television and press advertising each year. However, since 1999 (which coincides with the increased politicisation of government advertising around the GST advertising and the disbanding of OGIA) the government has increasingly chosen television advertising over press. Figure 3 shows that, while the rate of government advertising ebbs and flows, once the government decides to advertise, there is now a clear preference for TV. 
Figure 3 - Federal government advertising spending by medium, 1995-2005

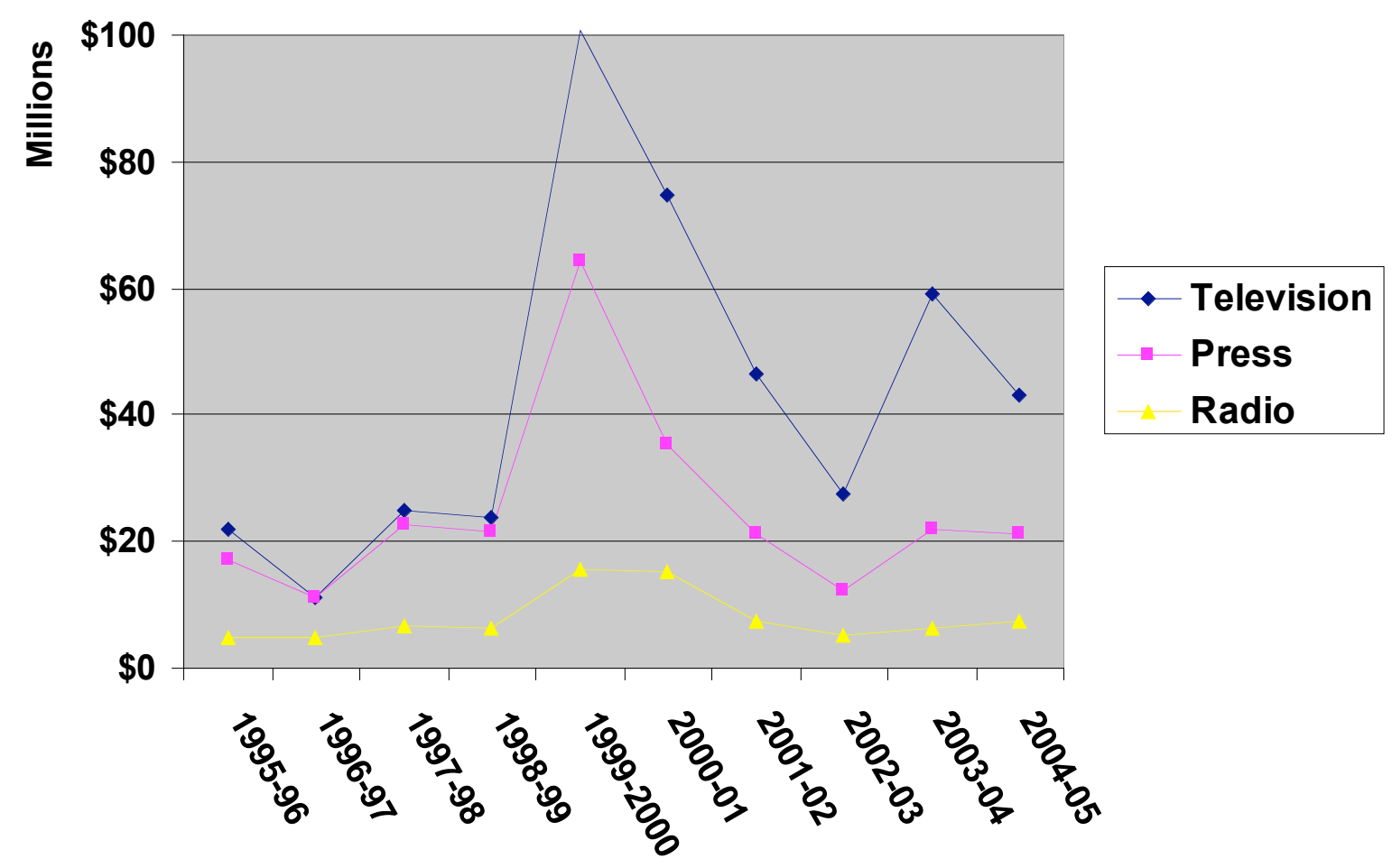

Source: Department of the Prime Minister and Cabinet (DPMC) (2005: 37).

Television is a favoured medium for election ads as politicians believe that it is the best way to reach swinging voters (Young, 2004: 46-9). As large scale federal government advertising campaigns have become increasingly politicised, they have also shifted to television.

There has also been a long-standing view held by political ad agents that television 'is the emotive medium...' (Braund, 1978: 350). This is significant in terms of content. The government's 'Unchain My Heart' GST ads in 2000 used Joe Cocker's emotive song along with images of Australian workers throwing off the chains of the old tax system. A voice over stated: 'Australia is currently being held back.... The Commonwealth government's new tax system will...move our country forward...' (Australian Government, 2000).

'Strengthening Medicare' TV ads in 2004 included a female voiceover (representing the government) who outlines 'changes' to Medicare while a woman with a baby on her lap smiles and responds: 'Well, that does sound good' (Australian Government, 2004d). Such ads have moved a long way from the convention which held that government advertising ought to be 'neutral'.

In political advertising, there has also been a recent trend towards using direct mail (letters, postcards or newsletters sent to voters' homes via the mail) to reach specific target audiences and deliver tailored and personalised messages (Young, 2004: 67-74). In government 
advertising, there is also increased use of mail and personalised letters. The 2004

'Strengthening Medicare' booklet sent to households (which was ostensibly about largely administrative matters: asking families to register for the new 'Medicare safety net') included a letter from the Prime Minister, signed (seemingly in handwriting but actually mass reproduced in colour printing) 'Yours sincerely, John Howard' (Australian Government, 2004b). The first page of a booklet on domestic violence also sent to households in the election year of 2004 included a photograph of Howard and his signature (Australian Government, 2004c).

\section{Audiences and consumption}

There has been little specific research on audiences and political or government advertising. However, what we do know suggests that, generally, Australians do not like either type of advertising. This is an important, and somewhat ironic, point given the growing use of both types of advertising and the extent to which Australian taxpayers fund them.

Advertising agent Ted Horton and former ALP pollster Rod Cameron have both admitted that Australians 'hate' political advertising (Young, 2004: 144-45). US research indicates that citizens often regard political advertising as 'more intrusive than routine commercial advertising' (Iyengar and Prior, 1999). In 1991, when the then ALP government proposed banning political ads on TV and radio, over half of those surveyed in a Saulwick Opinion Poll thought political advertising should be 'banned altogether' or 'banned during elections' and 30 per cent said they would prefer to receive no political advertising at all (Saulwick Poll, 1991). A 2004 Australia Post report found that 26 per cent of people did not want to receive political party advertising at all and, although parties and governments frequently opt for TV, only 16 per cent of survey respondents indicated that they actually wanted political TV ads (Australia Post, 2004: 3).

Government ads are less overtly negative in content than political advertising. However, we can still deduce some broad public distaste for them. A 2000 AC Nielsen AgePoll found that 77 per cent of those surveyed thought the government had spent too much on its GST advertising indicating that Australians are particularly sensitive to government waste (Hudson, 2000). The anti-terrorist advertising campaign of 2003 provoked ridicule and even overt public activism when citizens returned tens of thousands of fridge magnets which were part of a $\$ 15$ million mail out to eight million households (Peake, 2003). In 2005, following the government's IR ads, there were specific complaints to call centres about the volume, cost and content of the advertising; letters to the editor in newspapers and media experts suggesting that the ads could affect TV ratings 'with viewers choosing to switch off...' rather than bear the repetition (Canning, 2005a; Packham, 2005). 


\section{Conclusion}

Despite the Australian public's distaste for it, for the political class in Australia, the power of advertising and its suitability as a communication method is, at present, not in any doubt. Both major parties spend increasing amounts on advertisements during elections and both are loathe to relinquish advertising as their favoured communication medium once they reach office. As demonstrated by the movement of government advertising into the DPMC as well as the role of the Prime Minister's office in influencing ad content, advertising is not merely an afterthought of government business - it is now absolutely central to it.

While, in theory, government advertising is supposed to be quite separate and distinct from political advertising, there are growing similarities. This paper has highlighted some of the key points of convergence relating to spending, regulation, timing, advertising agents, media placement, content and audiences.

In Australia, in the largely unregulated environment of government advertising - with no external watchdog, no strong guidelines and a great deal of secrecy surrounding decisionmaking — partisanship, the benefits of incumbency and the desire to self-promote in a world of permanent campaigning and electoral insecurity, are proving to be far stronger influences on political practice than either convention or tradition. Theory and conventions have been cast aside so that, in practice, the lines between political and government advertising are now increasingly indistinct.

\section{References}

'Mate's Job', 1996, Sydney Morning Herald, 11 November: 14.

'Pearson's not the job for the boys', 2000, B\&T, 7 April: 1.

'Howard cautions against poll boost', 2004, Age, 3 August.

Abetz, The Hon Senator Eric, 2004, Private correspondence to Harry Evans, Clerk of the Senate, dated 31 August 2004, submitted as part of Department of Prime Minister and Cabinet (DPM\&C) response to questions on notice for the Senate Finance and Public Administration Committee Inquiry (FPAC) into Government Advertising, Department of the Senate, Canberra.

Auditor General, 1998, Taxation reform: Community Education and Information Programme, Australian National Audit Office, Canberra.

Australia Post, 2004, How voters want political parties to communicate with them: A summary of the latest research findings, Australia Post, Melbourne. 
Australian Government, 2000, 'Unchain My Heart' GST television advertisement (90 second version), broadcast 14 May, ATV10 Melbourne.

_ 2004a, 'New family assistance' newspaper advertisement, Herald Sun, 13 June.

_ 2004b, 'Strengthening Medicare' booklet and letter from the Prime Minister, Canberra, dated 26 May.

_2004c, 'Violence against women: Australia says "no"” campaign booklet, Canberra.

2004d, 'Strengthening Medicare' television advertisement (30 second version) broadcast: 20 June, Channel TEN10, Sydney.

Bartos, Stephen, 2004, Submission to the Senate FPAC Inquiry into Government Advertising, Department of the Senate, Canberra.

Blumenthal, Sydney, 1980, The permanent campaign: Inside the world of elite political operatives, Beacon Press, Boston.

Braund, Victoria, 1978, Themes in political advertising: Australian federal election campaigns 1949-1972, unpublished MA thesis, Department of Government, University of Sydney.

Buckley, Amanda, 1986, 'True Blue campaign launched', Australian Financial Review, 1 September: 1.

Canning, Simon, 2005a, ‘\$15m spent on IR “overkill”, Australian, 20 October: 15.

Canning, Simon, 2005b, 'TV loses out on federal revenue', Australian, 27 October: M17.

Clarke, Craig, 2004, 'Labor blames ads as support slips', Advertiser, 22 June: 13.

Department of Prime Minister and Cabinet (DPM\&C), 1982, Task force on departmental information report, July 1980, AGPS, Canberra.

2004, Submission to the Senate FPAC Inquiry into Government Advertising, Department of the Senate, Canberra.

2005, 'Answers to questions on notice', Senate FPAC Inquiry into Government Advertising, Department of the Senate, Canberra.

Evans, Harry, 2004, Submission to the Senate FPAC Inquiry into Government Advertising, 10 August, Department of the Senate, Canberra.

2005, Second submission to the Senate FPAC Inquiry into Government Advertising, 27 July, Department of the Senate, Canberra.

Flew, Terry, 2002, 'Television and pay TV', in (eds) Stuart Cunningham and Graeme Turner, The Media and Communications in Australia, Allen and Unwin, Crows Nest NSW.

Fox, Catherine, 1998, 'New team to sell tax reform', Australian Financial Review, 21 June: 33.

Franklin, Bob, 1994, Packaging politics: Political communications in Britain's media democracy, E. Arnold, London.

Golding, Peter, 1990, 'Political Communication and Citizenship: The Media and Democracy in an Inegalitarian Social Order', in (ed) M. Ferguson, Public Communication: The New Imperatives, Sage Publications, London.

Government Communications Unit (GCU), 2005, 'About the GCU', Department of Prime Minister and Cabinet,

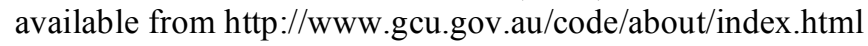

Grant, Richard, 2003-04, 'Research Note no.62, 2003-04: Federal government advertising’, Parliamentary Library, Parliament of Australia, Canberra.

Harris, Tony, 2005, 'Your taxes buy your vote', Australian Financial Review, 27 August: 62. 
Hawthorne, Maria, 2005, 'Govt's workplace ad campaign hits \$55m’, AAP Bulletins, 31 October.

Hudson, Phillip, 2000, 'Tax Poll Boost For PM', Age, 11 July: 1.

Iyengar, Shanto and Markus Prior, 1999, 'Political advertising: What effect on commercial advertisers?', paper available at http://www.stanford.edu/ siyengar/research/papers/advertising.html

McAllister, Ian and Clive Bean, 1997, 'Long-term electoral trends and the 1996 election' in (eds) C. Bean, M. Simms, S. Bennett and J. Warhurst, The politics of retribution: The 1996 federal election, Allen \& Unwin, St Leonards, N.S.W.

McCabe, Helen, 1998, 'PM's staff bungle indigenous adverts', Courier Mail, 26 Feburary.

McGregor, Richard, 1998, 'A footsoldier in command for the re-election battle', Australian, 5 September: 4.

McIntyre, Paul, 2005a, 'It may look like jobs for mates but familiarity breeds respect', Sydney Morning Herald, 11 August.

_ 2005b, 'Mates wheeling and dealing in bids to be government spinners', Sydney Morning Herald, 12 August.

Nielsen Media Research, 2005, 'Top Advertisers', AdNews, 25 March: L5.

NZ Audit Office, 1989, Suggested guidelines for a convention on publicly-funded government advertising and publicity, Office of the Controller and Auditor-General, Wellington, New Zealand.

NZ Cabinet Office, 1989, 'Circular (CO (89) 17): Guidelines for Government Advertising', New Zealand Government.

Packham, Ben, 2005, 'IR hotline runs riot', Herald Sun, 26 October.

Peake, Ross, 2003, 'Terror kits sent back in protest', Canberra Times, 14 February: 7.

Saulwick Poll, 1991, 'D0736: Saulwick Poll, March 1991', available from the Australian Social Science Data Archive, http://assda.anu.edu.au/polls/D0736.html

Seccombe, Mike, 1996, 'Gun buy-back advertising launch late and clouded in controversy', Sydney Morning Herald, 18 November: 4.

Senate Economics Legislation Committee (SELC), 2000, 'Official Committee Hansard: Australian Taxation Office - Outcome 2', Senate, Parliament of Australia, Canberra, 29 May 2000, available from http://parlinfoweb.aph.gov.au/piweb/Repository/Commttee/Estimate/Linked/s1053.pdf

Senate Finance and Public Administration Committee (FPAC), 2005, 'Estimates (Supplementary Budget Estimates): Department of the Prime Minister and Cabinet Discussion', Commonwealth Parliament of Australia, Canberra, available from http://parlinfoweb.aph.gov.au/piweb/Repository/Commttee/Estimate/Linked/43183.PDF

Sinclair, John, 2002, 'Advertising', in (eds) Stuart Cunningham and Graeme Turner, The Media and Communications in Australia, Allen and Unwin, Crows Nest NSW.

Sinclair, Lara, 2005a, ‘Agencies pitch for \$20m IR blitz’, Australian, 14 July.

Street, John, 2001, 'Packaging politics' in John Street, Mass Media, Politics and Democracy, Palgrave, New York.

Strickland, Katrina, 1996, 'Gun buyback ads escape \$20m chop', Australian, 19 September: 30.

Taylor, Mike, 1998, 'Howard's Dept takes on budget for federal ads', Canberra Times, 24 October: 6.

Tingle, Laura and Ben Mitchell and Megan Jones, 1996, 'PM aide pushed twice for agency', Age, 23 October: 3. 
Walker, Tony and Katharine Murphy and Aaron Patrick, 2001, 'Big guns in the political war rooms', Australian Financial Review, 6 October: 21.

Warneford, Penny, 1993, 'Election ads helped Libs lose', AdNews, 26 March: 15-6.

Windsor, Georgina, 1998, 'Cabinet drops PM's \$3m humpy ad’, Australian, 26 February: 4.

Young, Sally, 2003, 'Killing competition: political communication in Australia', AQ: Journal of Contemporary Analysis, vol.75, no.3, pp. 9-15.

_ 2004, The Persuaders: Inside the Hidden Machine of Political Advertising, Pluto Press, North Melbourne.

2005a, Second submission to the Senate FPAC Inquiry into Government Advertising, Department of the Senate, Canberra.

— 2005b, 'Political advertising: hey big spender!' in (eds) Marian Simms and John Warhurst, Mortgage Nation: The 2004 federal election, API Network, Perth. 


\section{University Library}

\section{- M I NER VA ACCESS}

A gateway to Melbourne's research publications

Minerva Access is the Institutional Repository of The University of Melbourne

Author/s:

YOUNG, SALLY

Title:

The convergence of political and government advertising: theory versus practice

Date:

2006

Citation:

Young, S. (2006). The convergence of political and government advertising: theory versus practice. Media International Australia incorporating Culture and Policy, (119), 99-111.

Publication Status:

Published

Persistent Link:

http://hdl.handle.net/11343/34907

File Description:

The convergence of political and government advertising: theory versus practice 


\section{University Library}

\section{- M M I N E R VA A gateway to Melbourne's research publications}

Minerva Access is the Institutional Repository of The University of Melbourne

Author/s:

YOUNG, S

Title:

The convergence of political and government advertising: theory versus practice

Date:

2006

Citation:

YOUNG, S. (2006). The convergence of political and government advertising: theory versus practice. Media International Australia incorporating Culture and Policy, 119 (May), pp.99-111

Persistent Link:

http://hdl.handle.net/11343/25647 